\title{
SIMULTANEOUS ESTIMATION OF MOXIFLOXACIN HYDROCHLORIDE AND DEXAMETHASONE SODIUM PHOSPHATE IN BULK AND IN OPHTHALMIC SOLUTION BY RP- HPLC
}

\author{
DHUMAL D. M., SHIRKHEDKAR A. A. *, NERKAR P. P., SURANA S. J. \\ Department of Pharmaceutical Chemistry, R. C. Patel Institute of Pharmaceutical Education and Research, Shirpur, Dist: Dhule (M.S.) India 425405
}

(Received: July 20, 2011 - Accepted: May 18, 2012)

\begin{abstract}
A new simple, precise, accurate and selective RP-HPLC method has been developed and validated for simultaneous estimation of Moxifloxacin Hydrochloride (MOX) and Dexamethasone Sodium Phosphate (DSP) in Ophthalmic Solution. The method was carried out on a Qualisil RP C-8 (250 mm x $4.6 \mathrm{~mm}, 5 \mu \mathrm{m})$ column with a mobile phase consisting of Methanol: Water $(75: 25 \mathrm{v} / \mathrm{v}) \mathrm{pH}$ adjusted to 3.0 with ortho-phosphoric acid of aqueous phase and flow rate of 1.0 mL min ${ }^{-1}$. Detection was carried out at $240 \mathrm{~nm}$. The retention time for MOX and DSP was found to be 2.22, and $7.26 \mathrm{~min}$, respectively. The MOX and DSP followed linearity in the concentration range of $10-60 \mu \mathrm{g} \mathrm{mL}^{-1}$ and 2- $12 \mu \mathrm{g} \mathrm{mL}-1$ with $\mathrm{r}^{2}=0.99$, respectively. The amounts of both these drugs estimated by proposed method were found to be in good agreement with label claim. The developed method was validated for sensitivity, accuracy, precision, ruggedness and robustness. The LOD and LOQ were found to be $0.30 \mu \mathrm{g} \mathrm{mL}^{-1}$ and $0.91 \mu \mathrm{g} \mathrm{mL}^{-1}$ for MOX and $0.10 \mu \mathrm{g} \mathrm{mL}-1$ and $0.30 \mu \mathrm{g} \mathrm{mL}^{-1}$ for DSP. The proposed method can be used for routine analysis of both these drugs simultaneously in their combined dosage form.
\end{abstract}

Keywords: Moxifloxacin Hydrochloride; Dexamethasone Sodium Phosphate; RP-HPLC

\section{INTRODUCTION}

Moxifloxacin Hydrochloride (MOX) is chemically 1-cyclopropyl-7-[(1S, 6S)-2, 8-diazabicyclo [4.3.0] non-8-yl]-6-fluoro-8-methoxy-4-oxo-quinoline3 -carboxylic acid hydrochloride is a $4^{\text {th }}$ generation fluoroquinolone broad spectrum antibiotic implicated in the treatment of conjunctivitis ${ }^{1}$. The drug is official in British Pharmacopeia ${ }^{2}$.

In literature, several analytical methods such as RP-HPLC ${ }^{3-11}$, UPLC 12 and some hyphenated techniques such as LC/MS/MS ${ }^{13}$, LC-MS ${ }^{14,15}$ have been reported for the determination of MOX single and in combination in biological fluids. Few RP-HPLC 16, 17, UV-Spectrophotometric, ${ }^{18-21}$ and HPTLC ${ }^{22,23}$ methods have been studied for determination of MOX in bulk and in pharmaceutical formulations. One RP-HPLC method has been studied for determination of moxifloxacin in combination with dexamethasone acetate in ear drop using SHIM-PACK VP-ODS $(150 \mathrm{~mm} \times 4.6 \mathrm{~mm}, 5 \mu \mathrm{m})$ column, with column temperature of $30^{\circ} \mathrm{C}$. The mobile phase consisted of phosphate buffer solution (which contained $0.02 \mathrm{~mol} \mathrm{~L}^{-1}$ sodium dihydrogen phosphate and $0.3 \%$ triethylamine)-methanol $(40: 60 \mathrm{v} / \mathrm{v}) \mathrm{pH}$ was adjusted to 3.0 using phosphoric acid. ${ }^{24}$.

Dexamethasone Sodium Phosphate (DSP) is chemically 9- fluoro-11b, 17, 21-trihydroxy-16a-methylpregna-1, 4-diene-3, 20-dione 21-(dihydrogen phosphate) disodium salt, is glucocorticoid class of steroids mainly used as anti-inflammatory and immunosuppressant ${ }^{25,26}$. The drug is official in Indian Pharmacopoeia ${ }^{27}$, British Pharmacopoeia ${ }^{28}$, United State Pharmacopeia ${ }^{29}$ and European Pharmacopoeia ${ }^{30}$. In literature, HPLC-MS/ESI ${ }^{31,32}$ and One RP-HPLC ${ }^{33}$ methods was found for determination of DSP in biological fluids, one RP-HPLC ${ }^{34}$, and UV-spectrophotometric method ${ }^{35}$ have been studied for estimation of DSP in combination with other drugs in bulk and in pharmaceutical formulations.

The chemical structures of both drugs are as shown in (Figure 1).

Combination of both these drugs in eye drop formulation is used for treatment of superficial eye infections and available in Indian market. ${ }^{36}$

To our knowledge no RP-HPLC method has been studied so far for the simultaneous determination of MOX and DSP in combined dosage form.

Therefore, an objective of this work is to develop and validated RPHPLC method for the simultaneous determination of both these drugs in their combined dosage form. The second objective is to validate the method as per the ICH guidelines, ${ }^{37-39}$.

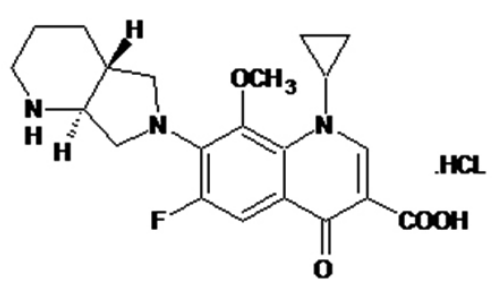

a)

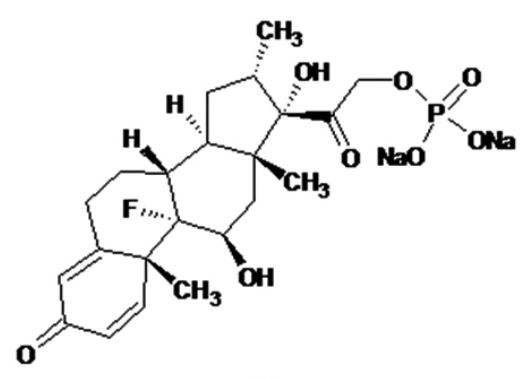

b)

Figure 1: Chemical structure of MOX (a) and DSP (b)

MATERIALS AND METHODS

Chemicals

Moxifloxacin Hydrochloride (99.0 \%) and Dexamethasone Sodium Phosphate $(98.9 \%)$ were obtained from Cipla, Mumbai, and Cadila Pharmaceutical Ltd, Ahmadabad, India as a gift sample respectively. Orthophosphoric acid (AR Grade), methanol (HPLC Grade), was purchased from Merck (India) Ltd., Worli, and Mumbai, India. Ophthalmic solution (Milflox DM) was purchased from Indian market, containing MOX $\left(5 \mathrm{mg} \mathrm{mL}^{-1}\right)$, DSP $\left(1 \mathrm{mg} \mathrm{mL}^{-1}\right)$.

Double distilled water of HPLC grade was prepared by distillation system. Instrumentation and Chromatographic Conditions

Analysis was performed on chromatographic system of Agilent Technologies 1200 series HPLC comprising G1311A Quaternary pump, G1315 D Diode Array Detector, G1328 B Manual Injector with $20 \mu \mathrm{L}$ loop. EZ Chrom Elite Chromatographic data station was used as a data processer. A LC-GC Qualisil C-8 column ( $250 \mathrm{~mm}$ x $4.6 \mathrm{~mm}$ i.d., $5-\mu \mathrm{m})$ was used for 
chromatographic separation under suitable conditions. The mobile phase consists of methanol and water $(75: 25 \mathrm{v} / \mathrm{v}) ; \mathrm{pH}$ adjusted to 3.0 with orthophosphoric acid at a flow rate of $1.0 \mathrm{~mL} \mathrm{~min}^{-1}$ and the run time was $9 \mathrm{~min}$. Before analysis both the mobile phase and sample solutions were filtered through a $0.45 \mu \mathrm{m}$ membrane filter and degassed for $15 \mathrm{~min}$ in an ultrasonicator. The detection of these drugs was carried out at $240 \mathrm{~nm}$. The UV- spectra of these two drugs in double distilled water is shown in (Figure 2).

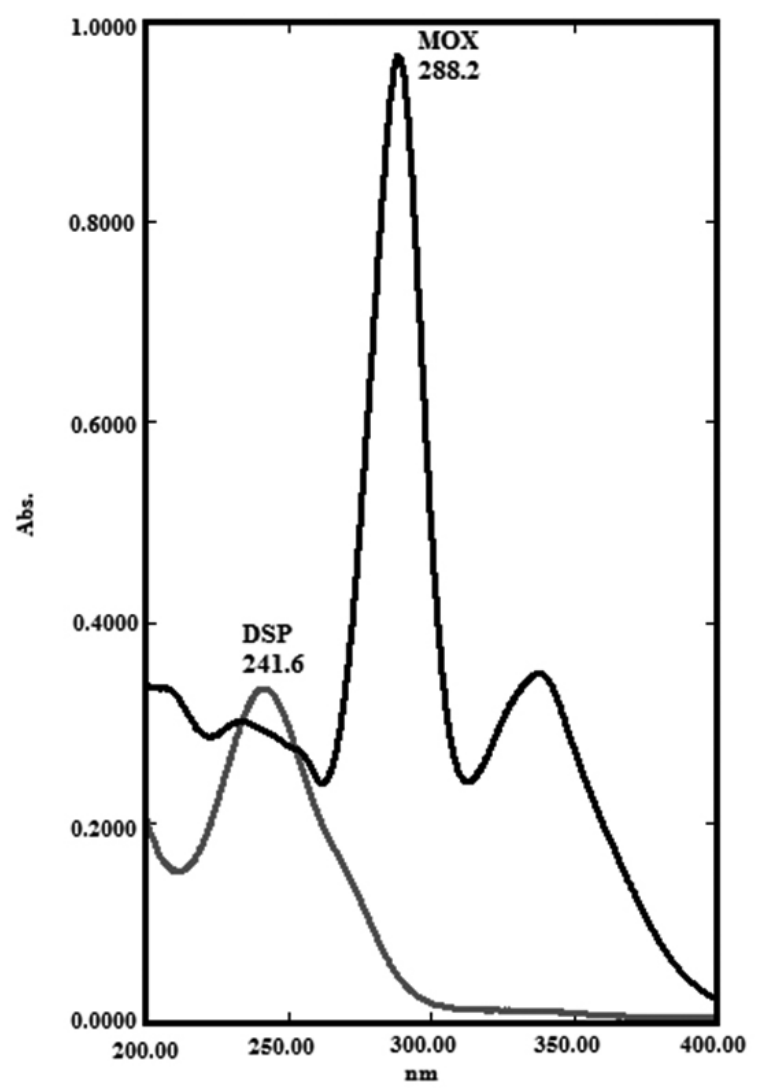

Figure 2: A typical overlain spectrum of standard MOX and DSP

Preparation of Stock Standard Solutions and Calibration Graphs

Stock standard solutions of $1 \mathrm{mg} \mathrm{mL}^{-1}$ of MOX and DSP were prepared separately in methanol. The stock solution of MOX was diluted with the mobile phase to give working standard solutions containing $10-60 \mu \mathrm{g} \mathrm{mL}-1$ concentrations, similarly the DSP stock solution was diluted with the mobile phase to give working standard solutions in the range $2-12 \mu \mathrm{g} \mathrm{mL}-1$. These standard solutions were injected for construction of calibration curves by plotting drug peak areas for each of the drugs against concentrations.

\section{Analysis of marketed tablet formulation}

An accurately measured volume of ophthalmic solution equivalent to $10 \mathrm{mg}$ of MOX and $2 \mathrm{mg}$ DSP was transfer into $100 \mathrm{~mL}$ volumetric flask containing $25 \mathrm{~mL}$ of methanol, and volume was made up to the mark with methanol, the resulting solution was filtered using $0.45 \mu \mathrm{m}$ filter (Mill filter, Milford, MA). From filtrate, $2 \mathrm{~mL}$ of solution was transferred into $10 \mathrm{~mL}$ volumetric flask and the volume was made up to mark with mobile phase to obtain the final concentration of $20 \mu \mathrm{g} \mathrm{mL}^{-1} \mathrm{MOX}$ and $4 \mu \mathrm{g} \mathrm{mL} \mathrm{L}^{-1}$ of DSP. Resulting solution was subjected to propose method and the amount of MOX and DSP were determined.

\section{Method Validation}

The HPLC method was validated in accordance with $\mathrm{ICH}$ guidelines

Precision

The precision of the method was studied as intra-day and inter-day. Intraday precision was determined by analyzing, the three different concentrations $20 \mu \mathrm{g} \mathrm{mL}^{-1}, 30 \mu \mathrm{g} \mathrm{mL}^{-1}$ and $40 \mu \mathrm{g} \mathrm{mL}^{-1}$ of MOX and $4 \mu \mathrm{g} \mathrm{mL}^{-1}, 6 \mu \mathrm{g} \mathrm{mL}{ }^{-1}$ and
$8 \mu \mathrm{g} \mathrm{mL}^{-1}$ of DSP, respectively, for three times in the same day. Day to Day variability was assessed using above mentioned three concentrations analyzed on three different days for inter-day precision.

Specificity and Selectivity

Specificity of the method was ascertained by analysing drug standard and sample. The analytes should have no interference from other extraneous components and be well resolved from them. Specificity is a procedure to detect quantitatively the analyte in presence of component that may be expected to be present in the sample matrix, while selectivity is the procedure to detect qualitatively the analyte in presence of components that may be expected to be present in the sample matrix.

Accuracy

To the pre-analyzed sample solution of $20 \mu \mathrm{g} \mathrm{mL}^{-1}$ of MOX and $4 \mu \mathrm{g} \mathrm{mL}^{-1}$ of DSP, a known amount of drug standards of MOX and DSP were added at 80,100 and $120 \%$ level and re-analysed using proposed method. The analysis was repeated for three times at each level.

Sensitivity

Sensitivity of the proposed method was estimated in terms of Limit of Detection (LOD) and Limit of Quantitation (LOQ). LOD $=3.3 \times \mathrm{ASD} / \mathrm{S}$ and $\mathrm{LOQ}=10 \mathrm{x} \mathrm{ASD} / \mathrm{S}$, where 'ASD' is the average standard deviation and ' $\mathrm{S}$ ' is the slope of the calibration curve.

Robustness

Robustness of the method was studied by making deliberate variations in the chromatographic conditions such as variation of $\mathrm{pH}( \pm 0.1)$ of the mobile phase; flow rate $\left( \pm 0.1 \mathrm{~mL} \mathrm{~min}^{-1}\right)$ and change in mobile phase composition (methanol $( \pm 2 \mathrm{~mL})$ : water $( \pm 2 \mathrm{~mL})$ ). The robustness of the method was studied by using sample solution containing $20 \mu \mathrm{g} \mathrm{mL}^{-1}$ of MOX and $4 \mu \mathrm{g} \mathrm{mL}^{-1}$ solution of DSP, respectively.

Ruggedness

Ruggedness of the method was studied by two different analysts using same experimental and environmental conditions. It was performed by injecting $20 \mu \mathrm{g} \mathrm{mL}^{-1}$ of MOX and $4 \mu \mathrm{g} \mathrm{mL}^{-1}$ solution of DSP. Peak area was measured for same concentration solutions for six times.

\section{RESULTS AND DISCUSSION} Phase

Selection of Chromatographic Conditions and Optimization of Mobile

Mobile phase was optimized with a view to separate MOX and DSP using Qualisil RP C-8 column $(250 \mathrm{~mm}$ x $4.6 \mathrm{~mm}$ i.d., $5 \mu \mathrm{m}$. Initially, methanol and water in the various proportions were tried as mobile phase but the splitting of the peaks for both these drugs was observed. Therefore, after adjustment of $\mathrm{pH}$ of aqueous phase, methanol and water in 75:25\% $v / v$ was tried for resolution of both these drugs. Good resolution and symmetric peaks were obtained for both drugs when the $\mathrm{pH}$ of the mobile phase (aqueous phase) was adjusted to 3.0. The flow rate of the mobile phase was $1.0 \mathrm{~mL} \mathrm{~min}^{-1}$. Under optimum chromatographic conditions, the retention time for MOX and DSP was found to be $\mathbf{2 . 2 2}$ and $\mathbf{7 . 2 6} \mathrm{min}$, respectively when the detection was carried out at 240 $\mathrm{nm}$. A typical chromatogram of two drugs is shown in (Figure 3).

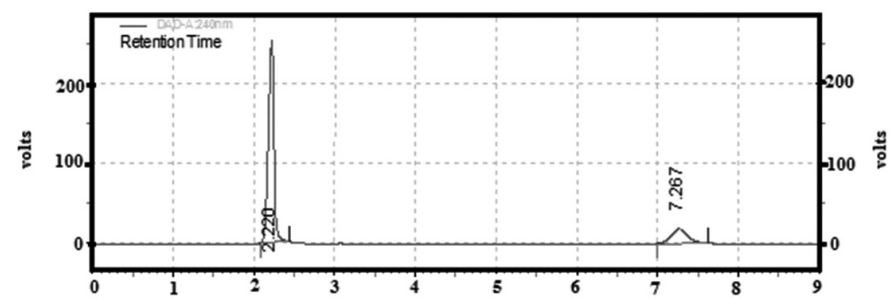

Figure 3: Chromatogram obtained for MOX and DSP standard in methanol: water $(75: 25 \mathrm{v} / \mathrm{v}), \mathrm{pH} 3.0$ (aqueous phase) as a mobile phase.

\section{Linearity}

The linearity was determined separately for MOX and DSP. Solutions of these drugs at six different concentrations were analyzed and calibration curves were constructed by plotting peak area against the respective concentrations. The method was evaluated by determination of the correlation coefficient and intercept values. The MOX and DSP followed linearity in the concentration range of $10-60 \mu \mathrm{g} \mathrm{mL}^{-1}$ and $2-12 \mu \mathrm{g} \mathrm{mL}^{-1}$; respectively. The results are shown in Table 1. 
Table 1: Linearity Studies.

\begin{tabular}{|l|c|c|}
\hline \multicolumn{1}{|c|}{ Parameter } & MOX & DSP \\
\hline Linearity $\left[\mu \mathrm{g} \mathrm{mL}^{-1}\right]$ & $10-60$ & $2-12$ \\
\hline Linearity Equation & $\mathrm{Y}=26468 \mathrm{X}+49911$ & $\mathrm{Y}=26041 \mathrm{X}+5698$ \\
\hline Slope $\pm \mathrm{SD}$ & $26468 \pm 436.03$ & $26041 \pm 155.00$ \\
\hline Intercept $\pm \mathrm{SD}$ & $49911 \pm 8267.66$ & $5698 \pm 774.64$ \\
\hline $\begin{array}{l}\text { Correlation } \\
\text { Coefficient } \pm \mathrm{SD}\end{array}$ & $0.999 \pm 0.0001$ & $0.999 \pm 0.0001$ \\
\hline
\end{tabular}

Precision

The precision study was evaluated on the basis of \% RSD value. The intra-day precision for moxifloxacin hydrochloride and dexamethasone sodium phosphate was found to be in the range $0.21-0.62$ and $0.16-0.61 \%$, respectively. And, the inter-day precision for MOX and DSP was found to be in the range $0.40-0.77$ and $0.14-0.49 \%$, respectively. The low values of $\%$ RSD indicate high precision of the method. Results of precision study are shown in Table 2.

Table 2: Results from Precision studies.

\begin{tabular}{|c|c|c|c|c|c|}
\hline \multirow[t]{2}{*}{ Conc. $[\mu \mathrm{g} / \mathrm{mL}]$} & \multicolumn{2}{|l|}{ MOX } & \multirow[t]{2}{*}{ Conc. $[\mu \mathrm{g} / \mathrm{mL}]$} & \multicolumn{2}{|c|}{ DSP } \\
\hline & $\begin{array}{c}\text { Amount Found in } \mu \mathrm{g} \\
\mathrm{mL} L^{-1} \\
{[\mathrm{n}=3] \pm \mathrm{SD}}\end{array}$ & $\%$ RSD & & $\begin{array}{l}\text { Amount Found } \\
\text { in } \mu \mathrm{g} \mathrm{mL} L^{-1} \\
{[\mathrm{n}=3] \pm \mathrm{SD}}\end{array}$ & $\begin{array}{c}\% \\
\text { RSD }\end{array}$ \\
\hline \multicolumn{6}{|c|}{ Intra - day Precision } \\
\hline 20 & $19.98 \pm 0.04$ & 0.21 & 4 & $4.02 \pm 0.02$ & 0.61 \\
\hline 30 & $29.59 \pm 0.18$ & 0.62 & 6 & $5.99 \pm 0.01$ & 0.29 \\
\hline 40 & $40.30 \pm 0.19$ & 0.47 & 8 & $7.99 \pm 0.01$ & 0.16 \\
\hline \multicolumn{6}{|c|}{ Inter - day Precision } \\
\hline 20 & $19.94 \pm 0.08$ & 0.40 & 4 & $4.01 \pm 0.01$ & 0.48 \\
\hline 30 & $29.72 \pm 0.23$ & 0.77 & 6 & $6.01 \pm 0.008$ & 0.14 \\
\hline 40 & $39.93 \pm 0.21$ & 0.54 & 8 & $7.97 \pm 0.03$ & 0.49 \\
\hline
\end{tabular}

\section{Specificity and Selectivity}

Specificity of the method was ascertained by comparing the chromatogram obtained from ophthalmic solution and standard drug. The retention times of the standard drugs and the drugs from ophthalmic solutions were same, so the method was specific. The method was also specific and selective because there was no interference from excipients in the ophthalmic solution. The method is quite selective. There was no other interfering peak around the retention time of MOX and DSP; also the base line did not show any significant noise.

Accuracy

The accuracy of the method studied at three different concentration levels i.e. $80 \%, 100 \%$ and $120 \%$ showed affordable \% recoveries in the range of $99.35-100.79 \%$ for MOX and $99.43-99.96 \%$ for DSP. The results are shown in Table 3 . The low value of $\%$ RSD indicates accuracy of the method.

Table 3: Results of Recovery Studies.

\begin{tabular}{|c|c|c|c|c|}
\hline \multirow{2}{*}{ Drugs } & $\begin{array}{c}\text { Label claimed } \\
\left(\mathrm{mg} \mathrm{mL}^{-1}\right)\end{array}$ & $\begin{array}{c}\text { Amount of } \\
\text { standard drug } \\
\text { added }(\%)\end{array}$ & $\begin{array}{c}\text { \% Drug } \\
\text { Recovered } \\
{[\mathrm{n}=3]}\end{array}$ & \% R.S.D. \\
\hline \multirow{3}{*}{ MOX } & \multirow{2}{*}{5} & 80 & 100 & 0.57 \\
\cline { 3 - 5 } & & 100 & 100.79 & 0.90 \\
\hline \multirow{2}{*}{ DSP } & \multirow{2}{*}{1} & 120 & 99.35 & 0.16 \\
\cline { 3 - 5 } & \multirow{2}{*}{1} & 80 & 99.49 & 1.19 \\
\cline { 3 - 5 } & & 100 & 99.43 & 0.92 \\
\hline
\end{tabular}

Sensitivity

The LOD for MOX and DSP was found to be 0.30 and $0.10 \mu \mathrm{g} \mathrm{mL}^{-1}$, respectively. The LOQ for MOX and DSP was found to be 0.91 and 0.30 $\mu \mathrm{g} \mathrm{mL}{ }^{-1}$, respectively. The low values of LOD and LOQ indicates adequate sensitivity of the method.

Robustness and Ruggedness study

Robustness of the method was studied by making deliberate changes in the chromatographic conditions and the effects on the results were examined. The content of the drugs were not adversely affected by these changes as evident from the low values of $\%$ RSD ( less than $2 \%$ ) indicating robustness of the method.

When the method was performed by two different analysts under the same experimental and environmental conditions it was found to be rugged and $\%$ RSD (less than $2 \%$ ) indicating ruggedness of the method.

Analysis of marketed tablet formulation

Six replicates of the samples solutions $(20 \mu \mathrm{L})$ were injected for quantitative analysis. The amounts of moxifloxacin hydrochloride and dexamethasone sodium phosphate estimated were found to $99.97 \%$ and $99.68 \%$, respectively.

System Suitability Test

According to USP, system suitability test are integral part of liquid chromatographic methods. They are used to verify that the resolution and reproducibility of the chromatographic system are adequate for the analysis to be done. Earlier prepared solutions for chromatographic conditions were tested for system suitability testing.

The results obtained from validation of the methods and system suitability studies are summarized in Table 4.

Table 4: Summary of system suitability study.

\begin{tabular}{|c|c|c|}
\hline Parameter & MOX & DPS \\
\hline Retention time [ $\left.\mathrm{t}_{\mathrm{R}}\right]$ & 2.22 & 7.26 \\
\hline Theoretical plates & 7169 & 5891 \\
\hline [N] & 21 & 67 \\
\hline Capacity factor [k'] & - & 21.13 \\
\hline Resolution [Rs] & 0.90 & 1.08 \\
\hline Asymmetry [T] &
\end{tabular}

\section{CONCLUSION}

The developed RP-HPLC method is simple, precise, accurate, selective and reproducible. The method has been found to be adequately rugged and robust and can be used for simultaneous determination of MOX and DSP in ophthalmic solution. 


\section{ACKNOWLEDGEMENT}

The authors are thankful to the Principal and management, R.C. Patel Institute of Pharmaceutical Education and Research, Shirpur (M.S.), India for providing the required facilities to carry out this research work.

\section{REFERENCES}

1.- The Merck Index - An Encyclopedia of Chemicals, Drugs and Biologicals, $14^{\text {th }}$ edn, Merck Research Laboratories, Whitehouse Station, New Jersey, USA, 6294, 2006.

2.- British Pharmacopoeia. The Stationary Office Medicinal and Pharmaceutical Substances (A-I), Vol.1, London, 1401-1403, 2009.

3.- J. D. Smet, K. Boussery, K. Colpaert, P. D. Sutter, P. D. Paepe, Decruyenaere, J. Bocxlaer J. V., J of Chromatogr. B, 877, 961-967, (2009).

4.- K. P. Chan., K. O. Chu, W.W. K. Lai, K. W. Choy, C. C. Wang, D. S. C. Lam, C. P. Pang, Anal. Biochem, 2006, 353, 30-36.

5.- Y. H. Xu, D. Li, X. Y. Liu, Y. Z. Li, J. Lu, J of Chromatogr B, (2010)

6.- T. Lemoineb, D. Breilha, D. Ducintb, J. Dubrezc, J. J. Jougonc, F. C Sauxa, J. of Chromatogra. B, 742, 247-254, (2000).

7.- S. T. Ulu, J. of Pharm. and Bio. Anal., 43, 320-324, (2007).

8.- A. L. Djurdjevic, M. J. Stankov, P. Djurdjevi'c, J. of Chromatogr B, 844, 104-111, (2006).

9.- N. Sultana, M. S. Arayne, M. Akhtar, S. Shamim, S. Gul, M. M. Khan, J. of Chin. Chem. Soc., 57, 708-717, (2010).

10.- M. Sher, M. A. Hussain, S. Jahan, A. R. Mufti, M. A. Shaheen, M. N. Hassan, Bashir S., Pak. J.of Sci., 62, 84-88, (2010).

11.- A. K. Hemanth Kumar, G. B. Ramachandran, Analyt Technol Biomed Life Sci, 877, 1205, (2009).

12.- G. K. Jain, N. Jain, S. A. Pathana, S. Akhtera, S. Talegaonkara, P. Chanderb, R. K. Khar, F. J. Ahmad, J.of Pharm. and Bio. Anal., 52, 110-113, (2010)

13.- D. H. Vu, R. A. Koster, J. W. Alffenaar, J. R. Brouwers, Anal. Tech. Biomed. Life Sci., 897, 1063-70, (2011).

14.- K. Vishwanathan, M. G. Bartlett, J. T. Stewart, J. Pharm. Biomed. Anal., 30, 961, (2002).

15.- A.D. Pranger, J. W. Alffenaar, A. M. Wessels, B. Greijdanus, J Anal Toxicol, 34, 135-41,

16.- P. Djurdjevic, A. Ciric, A. Djurdjevic, M. J. Stankov, J. of Pharm. and Biomed. Anal., 50, 117-126, (2009).

17.- P. R. Subbaiah, M. V. Kumudhavalli, C. Saravanan, M. Kumar, R. M. Chandira, Pharm. Anal. Acta,1, (2010).
18.- M. A. Sultan, Arab.J. of Chem., 2, 79-85, (2009).

19.- V. Dhillon, A. K. Chaudhary, Afri. J. Pharm. Sci. Phar., 1, 50-56, (2010).

20.- M. Misra, A.K. Misra, P. Zope, G. M. Panpalia, J. of Glob. Pharma Tech., 2, 21-27, (2010)

21.- S. K. Motwani, R. K. Khar, F. J. Ahmad, S. Chopra, Spectro Acta Part A: Mole. and Bimole. Spectro, 68, 250-256, (2007).

22.- S. K. Motwani, R. K. Khar, F. J. Ahmad, S. Chopra, K. Kohali, S. Talegaonkar, Anal. Chemi. Acta, 582, 75-82, (2007).

23.- F V. Dhillon, A. K. Chaudhary, Pharma. Methods, 1, 54-56, (2010).

24.- H. Dao-qiu, Y. Fa-hong, west china J. of Pharm. Sci., 02, (2009).

25.- The Merck Index - An Encyclopedia of Chemicals, Drugs and Biologicals, $14^{\text {th }}$ edn, Merck Research Laboratories, Whitehouse Station, New Jersey, USA, 2940, 2006.

26.- A. C. Moffat, M. D. Osselton., B. Widdop, Clarks Analysis of drug and poisons, 3rd edn, pharmaceutical press, 887 .

27.- Indian Pharmacopoeia. Ministry of Health and Family Welfare, Government of India, The Indian Pharmacoepoeial Commission, Ghaziabad, Vol.1, 1175-1176, 2007.

28.- British Pharmacopoeia. The Stationary Office Medicinal and Pharmaceutical Substances (A-I), Vol.1, London, 609-611, 2009.

29.- The United State Pharmacopeia/The National Formulary. The Official Compendia of Standards, Asian Edition, 592-594, 2005.

30.- European Pharmacopoeia 5.0, Council of Europe, Vol.2, France, 14041406, (2005).

31.- M. Zhanga, G. A. Mooreb, B. P. Jensena, E. J. Begga, P. A. Bird, J. of Chromatogr. B, (2010).

32.- H. Liu, X. Chena, S. Zhang, L. Qua, Y. Zhaoa, H. Liu, M. Dongc, J. of Chromatogr. B, 805, 255-260, (2004).

33.- H. W. Kwak, D. J. D’Amico, Kor. J. Ophthal., 9, 79-83, (1995).

34.- M. Pendela, E. Adams, J. Hoogmartens, J. of Pharm. and Biomed. Anal., 36, 751-757, (2004)

35.- Z. Zong-lin, L. Yu-qin, G. Xiang-cheng, Shangdong Pharmaceutical Industry, 1, (2005).

36.- h t t p : / / w w w. s u n p har m a. c o m / p r o d u c t - 1 is t . jsp?BrandName=MILFLOX\%20DM\%205ML

37.- ICH, Q2A: Text on Validation of Analytical Procedures, International Conference on Harmonization. October 1994.

38.- ICH, Q3B: Validation of Analytical Procedures: Methodology, International Conference on Harmonization. November 1996.

39.- ICH Harmonized Tripartite Guideline, Q2 (R1): Validation of Analytical Procedures: Text and Methodology. November 2005. 